\title{
Creating life-long anglers: impacts of a high school fishing program on youth fishing, related knowledge, confidence and perception of barriers
}

\author{
Nia A. Morales*, Ramesh Paudyal and Conor Hughes \\ Florida Fish and Wildlife Conservation Commission, Gainesville, FL, USA
}

Received: 4 September 2019 / Accepted: 26 November 2019

\begin{abstract}
Youth fishing programs are an important gateway into continued fishing participation. With the current focus on R3 (recruitment, retention, and reactivation), it is important to understand the impacts fishing programs can have on their participants' knowledge, confidence, and interest in continuation. In this study, we conducted retrospective pre-post surveys of participants in a high school fishing program in Florida, USA, and compared results to a group of non-participating peers. We found significant increases in knowledge and confidence related to fishing skills among participants and significantly higher skills and confidence reported by participants as compared to non-participants. We also saw higher levels of selfidentity as an angler as well as more desire to continue fishing on their own as compared to non-participants. The positive impacts of programs like this are important to the recruitment and retention of young anglers and continued evaluation of their effectiveness will lead to improved outreach programming.
\end{abstract}

Keywords: Youth fishing / angler recruitment / human dimensions / R3

Résumé - Créer des pêcheurs à la ligne à vie : impacts d'un programme de pêche à l'école secondaire sur la pêche chez les jeunes, connaissances connexes, fiabilité et perception des difficultés. Les programmes de pêche pour les jeunes sont une porte d'entrée importante vers une participation continue à la pêche. Compte tenu de l'accent mis actuellement sur R3 (recrutement, maintien en poste et réactivation), il est important de comprendre les répercussions que les programmes de pêche peuvent avoir sur les connaissances, la fiabilité et l'intérêt des participants à poursuivre leurs activités. Dans le cadre de cette étude, nous avons mené des sondages rétrospectifs avant et après la participation à un programme de pêche dans les écoles secondaires en Floride, aux États-Unis, et comparé les résultats à ceux d'un groupe de pairs non-participants. Nous avons constaté une augmentation importante des connaissances et de la fiabilité des participants en ce qui a trait aux compétences en matière de pêche, et des compétences et une fiabilité beaucoup plus élevées chez les participants que chez les non-participants. Nous avons également constaté des niveaux plus élevés d'auto-identité en tant que pêcheur à la ligne ainsi qu'un plus grand désir de continuer à pêcher seul par rapport aux non-participants. Les répercussions positives de programmes comme celui-ci sont importantes pour le recrutement et le maintien en poste des jeunes pêcheurs à la ligne et l'évaluation continue de leur efficacité permettra d'améliorer les programmes de sensibilisation.

Mots clés : Pêche des jeunes / recrutement des pêcheurs / dimensions humaines

\section{Introduction}

Fishing is a popular outdoor activity in the U.S. About 36 million people fished in 2016 and they spent about $\$ 46$ billion on equipment, licenses, trips, and other related expenses

\footnotetext{
${ }^{*}$ Corresponding author: nia.morales@myfwc.com
}

(USDI, 2016). Recreation expenditures generate significant economic impact both locally and nationally. These expenditures not only contribute to the overall economy and workforce, but they also are a key source of funding for conservation programs (ASA, 2013). Under the Federal Aid in Sport Fish Restoration Program in the U.S., natural resource agencies receive fish conservation funding from license sales and excise taxes collected on fishing-related expenditures 


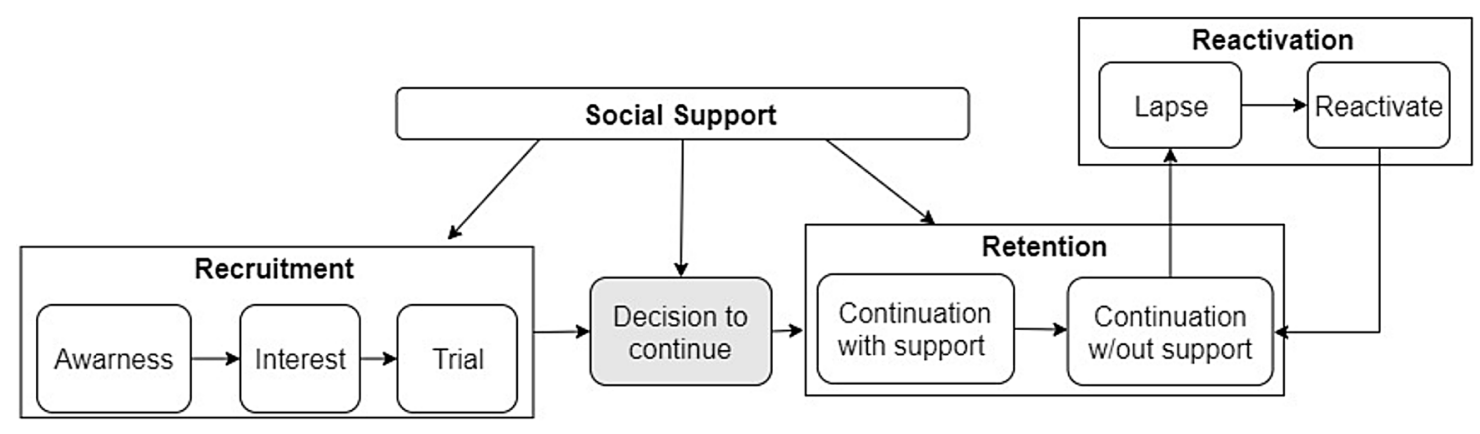

Self Identification

Fig. 1. ORAM Model (Source: Byrne and Dunfee, 2018).

(USFWS, 2000), and for most agencies this has remained the primary source of funding (Duda et al., 2010).

In addition to supporting conservation and management, fishing provides many personal and social benefits. Participation in outdoor activities, such as fishing, improves outcomes related to developmental and educational achievement among youths (Seaman et al., 2014) and enhances well-being on a variety of other psychological dimensions, such as self-esteem, sense of mastery, and social connectedness (Schell et al., 2012; Leonard, 2015). For instance, from a sample of youth attending a fishing camp in New Hampshire, Leonard (2015) found significant improvement in resilience, optimism, and selfesteem following the one-week experience. This study also found recreational fishing provides youths an opportunity for development of patience and self-discipline. Fishing, like other outdoor activities, also encourages youth and adults to develop an empathetic perspective to learn and feel concern about the environment and act responsibly toward the environment (Siemer and Knuth, 2001; Wells and Lekies, 2006; Chawla and Cushing, 2007, Hungerford and Volk, 1990; Chawla, 1998). Thus, a genuine outdoor recreation experience, such as fishing, can affect youth's lifelong perception and interaction with the natural world (Kellert, 2005).

About 11 million youths under 17 participated in fishing in the U.S. in 2016 with an average of 11 trips per participant for children under 12 years and 16 trips per participant for teens 13-17 years (RBFF and Outdoor Foundation, 2017). However, angling participation rates overall have been stagnant or in a declining trend since early 1990s in most U.S. states (USDI, 2016; Duda et al., 2010; SGMA, 2001). One study showed that the participation of 12-17 year olds in freshwater fishing declined by $8 \%$ between 1990 and 2000 (SGMA, 2001). There was a $0.4 \%$ net increase in angling population age six and up, from 2016 to 2017, setting a record of highest angler population since 2009. However, anglers made 300,000 fewer fishing outings in 2017, compared to 2016.

In response to the stagnant or negative trend of fishing participation in the U.S., many natural resource agencies have allocated their efforts to recruitment, retention, and reactivation (R3) programs (Walsh et al., 2008; Woltmann et al., 2008). The R3 initiatives are a vehicle to invest resources to use fishing outreach to increase license sales and for aquatic stewardship education (Siemer and Knuth, 2001). The programs aim to generate awareness and interest in a recreation activity by providing opportunities for people to try, support and encourage novice recreationists to build their skills until they are able to participate independently, and help lapsed recreationists become active participants (USFWS, 2018). Natural resources agencies often use activity participation as defining characteristics of recruitment, retention, and reactivation. However, researchers have argued that these concepts are more related to individual attitudes and socio-cultural environments than participation alone (Larson et al., 2013; Decker et al., 2001; Seng et al., 2007).

Fishing is often described as a life-long activity with early participation predicting continuation through adulthood (McManus et al., 2011). Research has shown that over $80 \%$ of current anglers were introduced to fishing during their childhood and that they carry positive memories about fishing, such as spending time outdoor with family and friends (RBFF and Outdoor Foundation, 2017). Thus, natural resource agencies are promoting youth fishing programs to introduce young anglers to the sport hoping to create potential for long term support for fisheries management.

Over the years, scholars and practitioners developed different recreation adoption models to conceptualize stages and connections of R3 components for hunting and fishing (Wentz and Seng, 2000; Larson et al., 2013; RBFF, 2017; Byrne and Dunfee, 2018). Natural resources agencies and NGOs have invested a considerable effort on implementing different programs, such as youth hunting/fishing, family events, camp programs, advanced hunting/fishing trainings, and mentoring programs (Larson et al., 2013). However, several of these programs lacked systematic research that made it difficult to determine effectiveness of outcome (Larson et al., 2013; Seng et al., 2007). The most recently proposed Outdoor Recreation Adoption Model (ORAM) conceptualizes R3 processes in eight stages (Fig. 1). The R3 stages in ORAM are similar to those proposed by Wentz and Seng (2000), but it includes a "decision to continue" step following the trial stage to connect recruitment and retention (Byrne and Dunfee, 2018).

The ORAM model suggests designing specific programs to offer for participants in different stages of the recreation 
adoption process. Many natural resources agencies and NGOs are using the ORAM model to plan and implement their R3 programs; however, research is limited regarding effectiveness of these fishing programs. In this study, we use the ORAM model as a basis to examine effectiveness of a fishing program in changing participants' awareness, interest, confidence, and perceived barriers related to fishing.

In 2016, the Florida Fish and Wildlife Conservation Commission (FWC) established a cooperative partnership with Recreational Boating and Fishing Foundation (RBFF), The Fishing League Worldwide (FLW) Foundation, and The Bass Federation (TBF) to implement outreach and communication strategies that have been identified in the National Outreach and Communication Program. A High School Fishing Grant Program was developed to increase participation in high school fishing clubs by supporting Student Angler Federation (SAF)-affiliated high school fishing clubs in Florida. The program received funding of $\$ 20,000$ in the fall of 2016 and schools were invited to submit application for the grant. Schools that had existing SAF affiliated fishing club or were interested to establish a new club were qualified to apply. Among the 54 schools that had submitted application, 46 schools were awarded grants of up to $\$ 500$ per school to help establish new high school angling clubs or expand existing clubs, with an emphasis on counties with a high Hispanic population. Among the participating schools, 11 schools had existing fishing clubs and the rest were interested in establishing new clubs. About 1200 students participated in this program and were involved in conservation and community service activities, local and state level high school fishing events, championships, and tournaments.

The program intended to promote education through fishing to retain these younger anglers and create lifelong anglers who value conservation of natural resources. The program used the ORAM model as a guideline for conducting program activities. The participating schools addressed the "recruitment," "decision to continue," and "retention" constructs through providing social support in the form of trial experiences and skills development. Further, their goal of creating lifelong anglers targeted the "self- identity" construct by offering opportunities to participate in fishing championships and tournaments to allow participants achieve sense of self-esteem and social connectedness.

Using ORAM as a framework, we conducted a retrospective pre/post assessment of the participants and nonparticipants of this fishing program with the goal of understanding the following:

- Changes in fishing interest and desire to continue among participants (related to "retention" step in the ORAM model).

- Changes in fishing related skills and confidence of implementing the skills among participants (related to "recruitment" and "social support" step).

- Comparison of skills, confidence, and fishing interest between participants and non-participants (also related to "recruitment" and "social support" step).

\section{Methods}

We developed a survey instrument using the ORAM steps and the objectives for the program's implementation (i.e. specific skills and tasks that were to be covered during the program). Cognitive testing with staff who were associated with the program was used to test the instrument. Using a retrospective pre/post design, we sent surveys to all participating schools. The retrospective pre/post design was chosen because it reduces the "response-shift bias", or program-produced changes in participants' understanding of the concepts being measured (Howard and Dailey, 1979). This design allows participants to rate themselves with one frame of reference on both the pre and post items (Pratt et al., 2000). A pre-letter was sent to describe the study and encourage participation. The paper surveys were sent to program coaches to distribute to program participants, and a comparison group of non-participants also via the coaches for each school. Nonparticipants were identified as home-room peers from coach classrooms. The surveys were distributed in the spring of 2017 and a reminder was sent two weeks after initial contact and follow-up contacts were made over the course of the following month. Coaches were reminded via email and researchers also called non-respondent schools to encourage participation in this evaluation.

Eighty-seven students from 13 of the 46 participating schools responded our survey. Schools who responded included both public and private schools and were from a variety of locations throughout the state of Florida. The survey included questions related to fishing participation, fishing knowledge and confidence, perceived barriers, social support, identity and future intention. Pairwise t-tests were used to assess pre and post comparisons and independent sample $t$-tests were used to compare post-test responses to nonparticipant responses. Cohen's $d$ was used to assess effect size $($ small $=0.2$, medium $=0.5$, and large $=0.8)$ of group differences.

\section{Results}

\subsection{Overall participation}

Of the respondents, 49 were non-participants and 38 were participants. The majority of respondents were students of color (Tab. 1). Fifty-one percent were juniors (more than any other individual class designation). Females comprised 33\% of program participants and $55 \%$ of non-participants. Most respondents, both participants and non-participants, had fished prior to the program (Fig. 2).

\subsection{Pre and post test results}

Pairwise analyses showed significant increases in knowledge for all of the skill areas and in confidence for most of the skill areas considered in this study (Tab. 2). Reeling (speed, reeling action, lure retrieval) was the only one skill set that participants reported no change in confidence before and after the program. However, there was also a significant increase in interest in fishing from pre $(M=3.47)$ to post $(M=3.87)$, $T=4.45, p<.01$ with a medium effect size (Cohen's $d=0.55$ ). All students who responded to the survey said they were somewhat $(N=9)$ to very $(N=29)$ likely to continue fishing. Fifty-one percent reported they didn't need more support to continue fishing while $31 \%$ indicated they would need more 
support. In terms of self-identification, $62 \%$ of participants identified themselves as anglers and $43 \%$ thought others would describe them as anglers.

We also assessed youth's perception of barriers to their continuation of fishing. Barriers considered in this study included lack of money, time, transportation, not knowing where to fish, not having people to fish with, and not knowing how to target fish effectively (i.e. not knowing what techniques or equipment to use). Although majority of the respondents perceived these barriers as minor or nil, more than $30 \%$ of the respondents reported 'not knowing how to target fish effectively' as a major barrier. Similarly, about $25 \%$ of the respondents considered 'not having transportation to go fishing' as a major barrier.

Table 1. Demographic comparison of participants and nonparticipants.

\begin{tabular}{lllll}
\hline Demographics & $\begin{array}{l}\text { Sample } \\
\text { average } \\
(n=87)\end{array}$ & $\begin{array}{l}\text { Participants } \\
(n=38)\end{array}$ & $\begin{array}{l}\text { Non- } \\
\text { participants } \\
(n=49)\end{array}$ & $p$-value \\
\hline $\begin{array}{l}\text { Race/Ethnicity (\%) } \\
\quad \text { Black }\end{array}$ & 27.9 & 18.9 & 34.7 & 0.30 \\
$\quad$ Hispanic & 29.1 & 37.8 & 22.4 & \\
$\quad$ White & 32.6 & 32.4 & 32.7 & \\
$\quad$ Mixed & 10.5 & 10.8 & 10.2 & \\
$\quad$ & & & & 0.05 \\
Gender (\%) & 54.1 & 66.7 & 44.9 & \\
$\quad$ Male & 45.9 & 33.3 & 55.1 & 0.41 \\
$\quad$ Female & & & 15.7 & 0.82 \\
Age (mean years) & 15.6 & 15.4 & 10 & \\
Grade level (mean) & 9.9 & 9.9 & & \\
\hline
\end{tabular}

Percentages for race/ethnicity and gender were compared using Chisquare test; age and grade level were compared using independent sample $t$-test.

\subsection{Comparisons between participants and non-participants}

When comparing between the two groups, participants of the program had higher post-program knowledge and confidence for each skill area than non-participants (Tab. 3). When asked to what extent they agreed with the statement "I plan to fish on my own", there was a significantly lower level of agreement from non- participants $(M=1.48)$, than participants $(M=3.43) T=6.61, p<.01$. Half $(51 \%)$ of nonparticipants responded " $\mathrm{n} / \mathrm{a}$ " or neutral to the question "I need more support to continue fishing" with an additional 14\% indicating they needed support and $35 \%$ indicated they did not. This is considerably lower than the $51 \%$ of participants who said they didn't need additional support to continue fishing. Only $28 \%$ of non-participants considered themselves anglers, versus $62 \%$ of participants. Twenty-two percent of nonparticipants indicated others would describe them as anglers compared to $43 \%$ of participants. However, perceptions of participants and non-participants did not differ for any aspects of barriers considered in this study (Tab. 3).

\section{Discussion}

Natural resources agencies invest their interest and resources in R3 programs hoping for improvement in recreational participation in fishing and hunting and a subsequent growth of license sales. Outdoor recreation adoption model (Byrne and Dunfee, 2018) conceptualizes R3 as an eight-step process and offers guidelines for natural resources agencies for planning and implementing programs for each of these steps. In an effort to contribute to the limited available research on effects of fishing programs on youth's participation on and continuity of the activity, this study examined effects of a high school fishing program on youth's awareness, interest, confidence, perceived barriers etc. related to fishing by taking a sample of participants and nonparticipants.

We found that the fishing program significantly improved awareness and confidence of fishing related skills among the

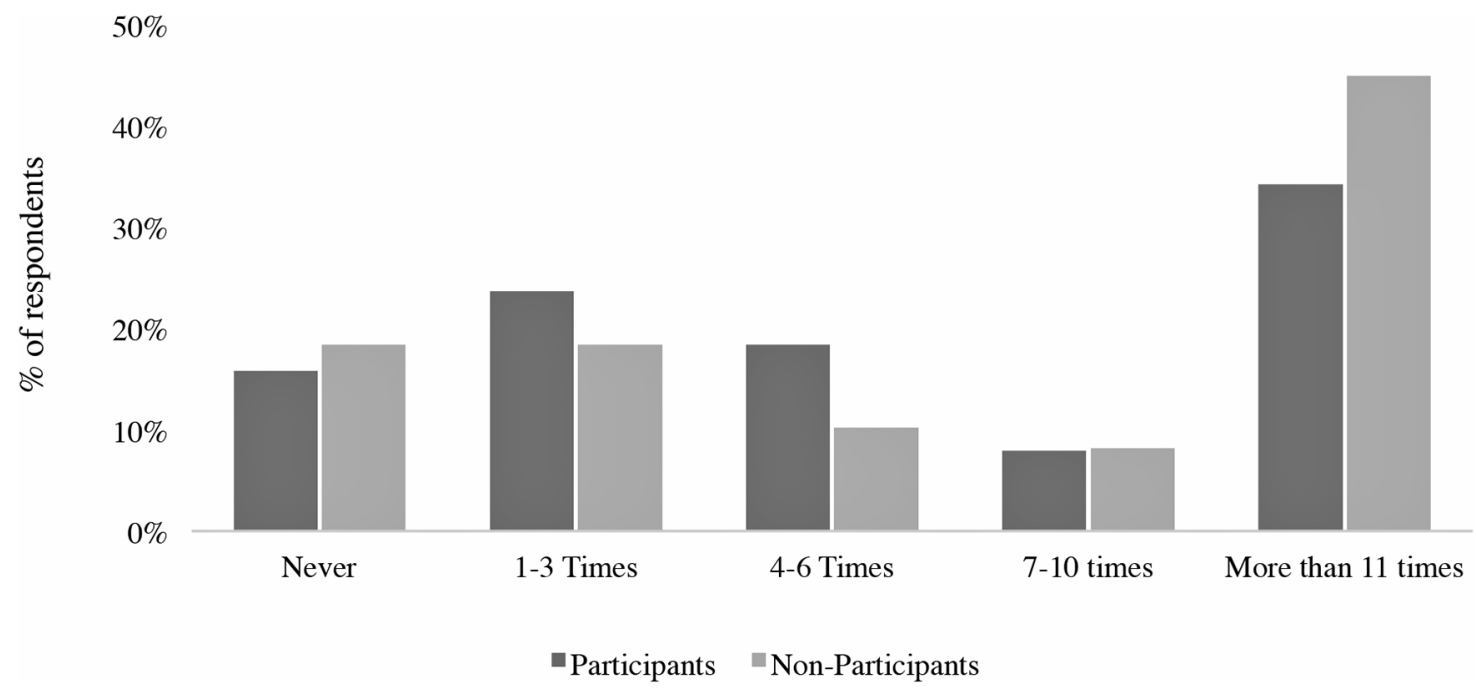

Fig. 2. Prior participation in fishing by participants and non-participants. 
N.A. Morales et al.: Knowl. Manag. Aquat. Ecosyst. 2020, 421, 3

Table 2. Pairwise analyses of pre and post knowledge and confidence showed significant differences before and after participation.

\begin{tabular}{|c|c|c|c|c|c|c|}
\hline Skill set ${ }^{*}$ & $N$ & Before & After & $T$ test & $p$ & Cohen's $d$ effect size \\
\hline \multicolumn{7}{|l|}{ Knowledge } \\
\hline Identifying fish & 36 & 3.1 & 3.9 & 4.3 & $<0.01$ & 0.7 \\
\hline Handling fish & 37 & 3.6 & 4.4 & 3.8 & $<0.01$ & 0.6 \\
\hline Casting & 37 & 3.7 & 4.3 & 2.9 & $<0.01$ & 0.5 \\
\hline Reeling & 37 & 3.6 & 4.2 & 2.9 & $<0.01$ & 0.5 \\
\hline Tying knots & 37 & 2.8 & 3.9 & 5.3 & $<0.01$ & 0.9 \\
\hline Lures & 36 & 3.2 & 4.1 & 3.9 & $<0.01$ & 0.7 \\
\hline Boating Safety & 37 & 3.6 & 4.2 & 3.3 & $<0.01$ & 0.5 \\
\hline \multicolumn{7}{|l|}{ Confidence } \\
\hline Identifying fish & 32 & 3.3 & 4.3 & 4.2 & $<0.01$ & 0.7 \\
\hline Handling fish & 37 & 3.8 & 4.3 & 3.2 & $<0.01$ & 0.5 \\
\hline Casting & 36 & 3.7 & 4.4 & 3.6 & $<0.01$ & 0.6 \\
\hline Reeling & 37 & 3.7 & 4.1 & 2.0 & 0.10 & 0.3 \\
\hline Tying knots & 37 & 3.3 & 4.1 & 4.5 & $<0.01$ & 0.7 \\
\hline Lures & 37 & 3.4 & 4.2 & 3.9 & $<0.01$ & 0.6 \\
\hline Boating Safety & 37 & 3.7 & 4.2 & 3.3 & $<0.01$ & 0.5 \\
\hline
\end{tabular}

${ }^{*}$ Response was measured on a scale of 1 (nothing at all) -5 (a lot).

Table 3. Comparisons of knowledge, confidence and perceived barriers between participants and non-participants.

\begin{tabular}{|c|c|c|c|c|c|c|c|}
\hline & \multicolumn{2}{|c|}{ Participants } & \multicolumn{2}{|c|}{ Non-participants } & \multirow[t]{2}{*}{$T$ test } & \multirow[t]{2}{*}{$p$} & \multirow[t]{2}{*}{ Cohen's $d$ effect size } \\
\hline & $n$ & Mean & $n$ & Mean & & & \\
\hline \multicolumn{8}{|l|}{ Knowledge } \\
\hline Identifying fish & 36 & 3.9 & 49 & 2.2 & 6.38 & $<0.01$ & 1.4 \\
\hline Handling fish & 37 & 4.4 & 48 & 3.0 & 4.52 & $<0.01$ & 1.0 \\
\hline Casting & 37 & 4.3 & 49 & 3.2 & 3.72 & $<0.01$ & 0.8 \\
\hline Reeling & 37 & 4.2 & 49 & 3.2 & 2.97 & $<0.01$ & 0.6 \\
\hline Tying knots & 37 & 3.9 & 49 & 2.5 & 4.30 & $<0.01$ & 0.9 \\
\hline Lures & 36 & 4.1 & 49 & 2.3 & 5.95 & $<0.01$ & 1.3 \\
\hline Boating Safety & 37 & 4.2 & 49 & 3.1 & 3.72 & $<0.01$ & 0.8 \\
\hline \multicolumn{8}{|l|}{ Confidence } \\
\hline Identifying fish & 33 & 4.2 & 45 & 2.6 & 5.61 & $<0.01$ & 1.2 \\
\hline Handling fish & 37 & 4.3 & 44 & 3.0 & 4.29 & $<0.01$ & 0.9 \\
\hline Casting & 37 & 4.4 & 45 & 3.1 & 3.83 & $<0.01$ & 0.8 \\
\hline Reeling & 37 & 4.1 & 44 & 3.2 & 2.69 & $<0.01$ & 0.6 \\
\hline Tying knots & 37 & 4.1 & 45 & 2.6 & 4.93 & $<0.01$ & 1.1 \\
\hline Lures & 37 & 4.2 & 45 & 2.5 & 6.15 & $<0.01$ & 1.3 \\
\hline Boating Safety & 37 & 4.2 & 45 & 3.4 & 2.67 & $<0.01$ & 0.6 \\
\hline \multicolumn{8}{|l|}{ Barriers } \\
\hline Money to purchase fishing equipment & 37 & 1.92 & 35 & 1.80 & 0.74 & .46 & 0.2 \\
\hline Time to fish & 31 & 1.87 & 38 & 1.87 & 0.01 & .99 & 0.0 \\
\hline Transportation to go fishing & 37 & 2.11 & 37 & 1.78 & 1.92 & .06 & 0.4 \\
\hline Knowing where to fish & 37 & 1.62 & 39 & 1.67 & -0.26 & .80 & 0.3 \\
\hline People to fish with & 37 & 1.84 & 39 & 1.62 & 1.23 & .22 & 0.1 \\
\hline Knowing how to target & 37 & 2.00 & 37 & 2.05 & -0.29 & .77 & \\
\hline
\end{tabular}

Note: Welch $t$ test statistics was used for all items of knowledge and confidence and first item of barrier as Levene test of equality variance indicated unequal variances between participants and non-participants. Knowledge and confidence were measured on a scale of 1 (nothing at all) -5 (a lot). Barriers were measured on a scale of not a barrier at all (1) - major barrier (3), with N/A option given to non-participants only.

participants, suggesting that the program sufficiently taught those skills. Other research has found that fishing programs with hands on training were more likely to improve best fishing practices among the youths compared to workshop trainings and that improvement in skills could lead to improving fishing practices (Delle Palme et al., 2016). Although both participants and non-participants perceived barriers related to fishing equally, some respondents said not knowing how to target fish 
effectively and not having transportation were major barriers. These findings could suggest that some youth may lack the support to participate in fishing. Higher outdoor activity (including fishing) involvement improves outcomes related to developmental and educational achievement. However, parent's lack of awareness and support toward these activities could affect a child's ability to do these activities (Seaman et al., 2014). Social support, including the support of family members, is an important aspect of the ORAM model (Byrne and Dunfee, 2018; Duda et al., 2010). Our findings add to the importance of high school fishing programs and clubs to help youth engage in the outdoors, access fishing areas, learn the specific skills they will need to be successful anglers, and to overcome barriers that are limiting them from continued participation. We further suggest that fishing programs should attempt to reach out to the participants' parents and other social connections to improve participants' social support to facilitate their continuation of fishing.

The ORAM model suggests that the decision to continue stage occurs, to some extent, throughout all stages of the model, but formation of identity (as an angler) plays important role for the decision to continue following first trial (Byrne and Dunfee, 2018). Our findings suggest that youth's perception of their identity as an angler was significantly higher among participants than non-participants. Given that participants and non-participants were not different in terms of past fishing experience, we posit that the fishing program we evaluated helped students realize their identity as an angler. This finding, in line with the ORAM model thus suggests that a youth fishing program should not only offer the trial opportunities, but also help the participants develop self-identification as an angler to increase chances of participants of these fishing programs continue to fish on their own. The year-round programs like this could be beneficial in helping participants attain sense of connectedness and self-identity.

While not a focus of this study, we also found that participants were more diverse than the general angling population. Since the goals of R3 programs are to increase participation in fishing and hunting, many programs are also directing efforts at broadening participation to include underrepresented groups. One of the goals of this program was also to increase participation among youth of color. Historically, rates of angler participation have differed substantially by demographic measures such as race and ethnicity. Research has consistently shown disproportionately less angling participation among people of color compared to whites, even when accounting for other demographic characteristics (e.g., age, gender, etc.) (Fedler and Ditton, 2001; Floyd and Lee, 2002; Hunt and Ditton, 2002; Lee et al., 2016). The underlying reasons for this underrepresentation range from structural constraints (i.e. limited access, limited discretionary funds for recreation), perceived or actual discrimination (historical or current actions that deter people of color from outdoor spaces), and cultural or social differences in preferences for outdoor recreation (Floyd and Johnson, 2002; Johnson et al., 2001). In other areas, changes in demographics (ageing out of older white anglers and increasing populations of color) are influencing the rates of fishing participation (Schroeder et al., 2008). Programs that target underrepresented groups can play an important role in recruiting and retaining diverse youth anglers.

\subsection{Management implications}

While our research suggests that the fishing program we evaluated successfully improved participants interest, awareness, and confidence in fishing and fishing related skills, the important research implication is to establish criteria that makes fishing programs successful. The researchers recognize the limitations of this study, in that we had a small sample to draw from. However, we determined that the methods and information gleaned from this research is valuable to other agencies/organizations who are interested in implementing and evaluating similar programs. Further, coaches/schools were not initially told to expect an evaluation instrument; this may have negatively impacted response. The FWC has since grown the high school fishing program and now provides all clubs with an educational curriculum that contains lessons and activities that focus on conservation and resource management (an area that was not previously emphasized). As clubs move through the curriculum, the participants also have the opportunity to practice and enhance their fishing techniques throughout the school year. A partner of the program provides each club with fishing poles and assorted tackle. Other partner organizations serve as additional mentorship resources for the clubs, assist with fishing tackle knowledge and use, and help with club events and activities throughout the duration of the program. By helping create a structured environment, such as high school fishing, that can last the school year, this will allow for more of a chance that students will be more inclined to participate than simply picking it up for the first time with no support system to build from. The new iteration of the program is currently being evaluated and the FWC will continue to run the high school fishing program for the 2019-2020 school year. As this program is becoming more established and communication with coaches regarding the evaluation process improves, we expect response to increase. Becoming an angler is part of social process that includes a series of exposures over time, including the initial experience that is critical to the long-term retention within the activity (Auger et al., 2018). High school fishing programs like the one evaluated in this study, as well as other programs including camps, fishing derbies, and family fishing days are all important interactions that could culminate in self-identification as an angler and continued participation in the activity. Future research should focus on the effectiveness of these programs to better understand the ORAM model as a theoretical framework to explain the process of recruitment, retention, and reactivation. This will help determine best practices for organizations and agencies who wish to implement or improve their own programming.

\section{References}

ASA (American Sportfishing Association, Responsive Management, Oregon Department of Fish and Wildlife, and Southwick Associates). 2013. Exploring recent increases in hunting and fishing participation. Report produced under multi-state conservation grant.

Auger D, Leclerc V, Roult R, Adjizian JM. 2018. Review of best practices in recruitment and retention of North American hunters and anglers. Society Leisure 41: 472-484. 
Byrne R, Dunfee M. 2018. Evolution and Current Use of the Outdoor Recreation Adoption Model. http://www.cahss.org/wp-content/ uploads/2018/08/RB Evolution-and-Current-Use-of-the-ORAM FINAL.pdf

Chawla L. 1998. Significant life experiences revisited: A review of research on sources of environmental sensitivity. $J$ Environ Educ 29: 11-21.

Chawla L, Cushing DF. 2007. Education for strategic environmental behavior. Environ Educ Res 13: 437-452.

Decker DJ, Brown TL, Siemer WF. 2001. Understanding hunting participation. In: Decker DJ, Brown TL, Siemer WF, eds. Human dimensions of wildlife management in North America. Bethesda, MD: The Wildlife Society, pp. 289-306.

Delle Palme CA, Nguyen VM, Gutowsky LFG, Cooke SJ. 2016. Do fishing education programs effectively transfer 'catch-and-release' best practices to youth anglers yielding measurable improvements in fish condition and survival? Knowl Manag Aquatic Ecosyst 417: $1-8$.

Duda MD, Jones MF, Criscione A. 2010. The sportsman's voice: Hunting and fishing in America. Venture Pub., Inc.

Fedler AJ, Ditton RB. 2001. Dropping out and dropping in: a study of factors for changing recreational fishing participation. Am J Fish Manag 21: 283-292.

Floyd MF, Johnson CY. 2002. Coming to terms with environmental justice in outdoor recreation: A conceptual discussion with research implications. Leisure Sci 24: 59-77.

Floyd MF, Lee I. 2002. Who buys fishing and hunting licenses in Texas? Results from a statewide household survey. Human Dimens Wildlife 7: 91-106.

Howard GS, Dailey PR. 1979. Response-shift bias: a source of contamination of self-report measures. J Appl Psychol 64: 144150 .

Hungerford HR, Volk TL. 1990. Changing learner behavior through environmental education. J Environ Educ 21: 8-21.

Hunt KM, Ditton RB. 2002. Freshwater fishing participation patterns of racial and ethnic groups in Texas. North Am J Fish Manag 22: $52-65$.

Johnson CY, Bowker JM, Cordell K. 2001. Outdoor recreation constraints: an examination of race, gender, and rural dwelling. Southern Rural Sociol 17: 111-133.

Kellert SR. 2005. Building for life: Designing and understanding the human-nature connection. Washington, DC: Island Press.

Larson LR, Decker DJ, Stedman RC, Siemer WF, Baumer MS, Enck JW. 2013. Hunter Recruitment and Retention in New York: A Framework for Research and Action. Human Dimensions Research Unit Series Publication 13-04. Department of Natural Resources, Cornell University, Ithaca, N.Y. 72 pp.

Lee KJ, Scott D, Floyd MF, Edwards MB. 2016. Social stratification in fishing participation in the United States: a multiple hierarchy stratification perspective. J Leisure Res 48: 245-263.

Leonard S. 2015. The benefits of recreational fishing in adolescence. Unpublished Masters Thesis. University of New Hampshire.

McManus A, Hunt W, Storey J, White J. 2011. Identifying the health and well-being benefits of recreational fishing. Curtin University, AU: Centre of Excellence for Science, Seafood and Health, Curtin Health Innovation Research Institute.
Pratt CC, McGuigan WM, Katzev AR. 2000. Measuring program outcomes: using retrospective pretest methodology. Am J Evaluat 21: 341-349.

RBFF (Recreational Boating and Fishing Foundation) and the Outdoor Foundation. 2017. Special Report on Fishing. Alexandria, VA.

Schell L, Cotton S, Luxmoore M. 2012. Outdoor adventure for young people with a mental illness. Early Interv Psychiatry 6: 407-414.

Schroeder SA, Nemeth ML, Sigurdson RE, Walsh RJ. 2008. Untangling the line: constraints to fishing participation in communities of color, in Proceedings of the American Fisheries Society Symposium, 2008, 67.

Seaman J, Sharp EH, McLaughlin S, Tucker CJ, Van Gundy KT, Rebellon CJ. 2014. A Longitudinal Study of Rural Youth Involvement in Outdoor Activities throughout Adolescence: Exploring Social Capital as a Factor in Community-Level Outcomes. Kinesiology Scholarship, Paper 240.

Seng PT, Byrne RR, Sanders S, McCool D. 2007. National Shooting Sports Foundation: Best Practices Workbook for Hunting and Shooting Recruitment and Retention. Mishawaka, IN: D. J. Case \& Associates, Inc.

Siemer WF, Knuth BA. 2001. Effects of fishing education programs on antecedents of responsible environmental behavior. $J$ Environ Educ 32: 23-29.

Sporting Goods Manufacturer Association. 2001. The SGMA report 2001: teen and pre-teen participation trends, 1990-2000. West Palm Beach, Florida.

USFWS (U.S. Fish and Wildlife Service). 2000. Federal Aid in Sport Fish Restoration Handbook, Fourth Edition. Washington, D.C.

USFWS (U.S. Fish and Wildlife Service) 2018. What is R3? Recruitment, retention and reactivation explained. https://www. fws.gov/midwest/news/WhatIsR3.html. Accessed: 07/15/2019

USDI (U.S. Department of the Interior, U.S. Fish and Wildlife Service, and U. S. Department of Commerce, U. S. Census Bureau) 2016. National survey of fishing, hunting, and wildlife-associated recreation. Washington, D.C.: U.S. Government Printing Office.

Walsh RJ, Levitt JT, Nemeth ML. 2008. The Minnesota Department of Natural Resources' Fishing in the Neighborhood program. In: Eades RT, Neal JW, Lang TJ, Hunt KM, Pajak P, eds. Urban and community fisheries programs: Development, management, and evaluation. Bethesda, Maryland: American Fisheries Society, Symposium 67, 261-271.

Wells NM, Lekies KS. 2006. Nature and the life course: Pathways from childhood natural experiences to adult environmentalism. Children Youth Environ 16: 1-24.

Wentz J, Seng P. 2000. Meeting the Challenge to Increase Participation in Hunting and Shooting. Newtown, CT: National Shooting Sports Foundation.

Woltmann EF, Kozlowski G, Guthrie CA. 2008. Fisheries management and aquatic education in the Long Island. New York City area: lessons learned over the past 30 years. In: Eades RT, Neal JW, Lang TJ, Hunt KM, Pajak P, eds. Urban and community fisheries programs: development, management, and evaluation. Bethesda, Maryland: American Fisheries Society, Symposium 67, 293-304.

Cite this article as: Morales NA, Paudyal R, Hughes C. 2020. Creating life-long anglers: impacts of a high school fishing program on youth fishing, related knowledge, confidence and perception of barriers. Knowl. Manag. Aquat. Ecosyst., 421, 3. 